\title{
Parental influences on adolescents' physical activity and sedentary behavior: longitudinal findings from Project EAT-II
}

\author{
Katherine W Bauer ${ }^{1,2,3^{*}}$, Melissa C Nelson, Kerri N Boutelle, Dianne Neumark-Sztainer
}

Since publication of our article [1], we observed an error in the coding of the moderate and vigorous physical activity (MVPA) variable. This error affects the mean level of MVPA in the sample, but does not significantly change any of the associations observed between parentalbehaviors and adolescents' physical activity. Please find below a description of the amendments. Sentence numbers are counted from the beginning of the section/ subsection. Amended version of tables 1 and 2 are also presented here.

In the "Results" section of the Abstract, the end of the first sentence should read as follows:

"after five years in young adult males ( $\mathrm{p}$ for trend $\leq .02)$."

In the same section, the next sentence should read:

"The positive relationship between maternal encouragement and MVPA approached significance among high-school aged females ( $\mathrm{p}$ for trend $=.06$ ), and a positive relationship between parental encouragement and MVPA approached significance among high school-aged males ( $\mathrm{p}$ for trend $=.05$ ).

In the "Results" section of the article, the second sentence should read:

"At Time 2, participants reported engaging in MVPA between 3.9 and 6.8 hours per week and reported watching TV/video between 17.1 and 19.2 hours per week ..."

\footnotetext{
* Correspondence: bauer223@umn.edu

'Division of Epidemiology \& Community Health, School of Public Health,

University of Minnesota, Minneapolis, Minnesota, USA

Full list of author information is available at the end of the article
}

In the Physical activity section of the Results:

The end of the second sentence should read:

“years later (p for trend $\leq .02) . "$

The middle of the third sentence should read:

" engaged in MVPA 2.2 more hours..."

The middle of the fourth sentence should read:

"participating in 5.1 hours of MVPA per week compared to 7.3 hours per week..."

The sixth sentence should read:

"among younger and older males ( $\mathrm{p}$ for trend $\leq .01$ )"

and... "among older females ( $\mathrm{p}$ for trend $=.05$ )" should not be present.

The end of the seventh sentence should read:

"among older males remained ( $\mathrm{p}$ for trend $\leq 02$ )"

The end of the eighth sentence should read:

“approached significance (p for trend = .05)."

Table 1 Adolescent reports of parental influence variables at Time 1 and adolescent physical activity and sedentary behaviors at Time 2 by gender and cohort: Descriptive statistics

\begin{tabular}{lllllllllll}
\hline \multicolumn{10}{l}{ Hours of MVPA per week row should read: } \\
\hline Hours of & 356 & 6.82 & 749 & 6.43 & 429 & 4.65 & 936 & 3.86 & 1.15 & .24 \\
MVPA per & & $(.23)$ & & $(.16)$ & & $(.21)$ & & $(.14)$ & & \\
week & & & & & & & & & & \\
\hline
\end{tabular}


Table 2 Adolescents physical activity at Time 2 by adolescent-reported parental factors at Time 1: 5-year longitudinal associations

\begin{tabular}{|c|c|c|c|c|c|c|c|c|}
\hline & & \multirow[t]{2}{*}{$\mathrm{n}^{\mathrm{a}}$} & \multicolumn{4}{|c|}{$\begin{array}{c}\text { Model } 1^{\text {b }} \text { Adjusted Mean Hours of MVPA per Week } \\
\text { by Level of Parental Factors }\end{array}$} & \multirow[t]{2}{*}{$\begin{array}{l}\text { Model } 1^{b} \\
p \text { for trend }\end{array}$} & \multirow[t]{2}{*}{$\begin{array}{l}\text { Model } 2^{c} \\
p \text { for trend }\end{array}$} \\
\hline & & & Not at all & A little & Somewhat & Very much & & \\
\hline \multicolumn{9}{|l|}{ Maternal Encouragement to be Active } \\
\hline & Younger Males & 324 & 6.4 & 7.0 & 6.9 & 7.3 & 0.35 & 0.79 \\
\hline & Older Males & 731 & 5.1 & 5.7 & 6.1 & 7.3 & $<0.01$ & $<0.01$ \\
\hline & Younger Females & 395 & 3.6 & 4.0 & 4.5 & 5.2 & 0.02 & 0.06 \\
\hline & Older Females & 907 & 4.0 & 3.9 & 4.0 & 3.9 & 0.79 & 0.17 \\
\hline \multicolumn{9}{|l|}{ Mother Cares About Staying Fit } \\
\hline & Younger Males & 325 & 6.2 & 6.4 & 7.8 & 6.8 & 0.30 & 0.97 \\
\hline & Older Males & 732 & 6.1 & 5.9 & 6.9 & 6.4 & 0.42 & 0.77 \\
\hline & Younger Females & 396 & 3.6 & 4.6 & 4.5 & 5.2 & 0.06 & 0.55 \\
\hline & Older Females & 911 & 3.9 & 3.8 & 3.8 & 4.2 & 0.46 & 0.77 \\
\hline \multicolumn{9}{|l|}{ Paternal Encouragement to be Active } \\
\hline & Younger Males & 317 & 5.7 & 5.8 & 6.8 & 7.9 & $<0.01$ & 0.05 \\
\hline & Older Males & 708 & 5.4 & 5.6 & 6.9 & 7.0 & $<0.01$ & $<0.01$ \\
\hline & Younger Females & 361 & 4.2 & 4.6 & 4.8 & 5.1 & 0.23 & 0.68 \\
\hline & Older Females & 877 & 3.7 & 4.2 & 3.6 & 4.2 & 0.40 & 0.57 \\
\hline \multicolumn{9}{|l|}{ Father Cares About Staying Fit } \\
\hline & Younger Males & 317 & 4.9 & 6.3 & 7.4 & 7.6 & $<0.01$ & 0.19 \\
\hline & Older Males & 703 & 5.7 & 6.0 & 6.9 & 7.0 & 0.01 & 0.02 \\
\hline & Younger Females & 362 & 3.8 & 5.0 & 4.9 & 4.9 & 0.11 & 0.12 \\
\hline & Older Females & 876 & 3.6 & 4.1 & 4.0 & 4.1 & 0.24 & 0.51 \\
\hline
\end{tabular}

\section{Author details}

'Division of Epidemiology \& Community Health, School of Public Health, University of Minnesota, Minneapolis, Minnesota, USA. ${ }^{2}$ Division of General Pediatrics and Adolescent Health, Department of Pediatrics University of Minnesota, Minneapolis, Minnesota, USA. ${ }^{3}$ Department of Pediatrics and Psychiatry, University of California San Diego, San Diego, California, USA.

Received: 10 February 2011 Accepted: 21 February 2011

Published: 21 February 2011

\section{Reference}

1. Bauer KW, Nelson MC, Boutelle KN, Neumark-Sztainer D: Parental influences on adolescents' physical activity and sedentary behavior: longitudinal findings from Project EAT-II. Int I Behav Nutr Phys Act 2008, $5: 12$.

doi:10.1186/1479-5868-8-12

Cite this article as: Bauer et al: Parental influences on adolescents' physical activity and sedentary behavior: longitudinal findings from Project EAT-II. International Journal of Behavioral Nutrition and Physical Activity 2011 8:12

\section{Submit your next manuscript to BioMed Central} and take full advantage of:

- Convenient online submission

- Thorough peer review

- No space constraints or color figure charges

- Immediate publication on acceptance

- Inclusion in PubMed, CAS, Scopus and Google Scholar

- Research which is freely available for redistribution

Submit your manuscript at www.biomedcentral.com/submit
C Biomed Central 